$\mathbb{T}$ periodica polytechnica

Architecture

$41 / 2(2010) 4347$

doi: 10.3311/pp.ar.2010-2.01

web: http://www.pp.bme.hu/ar

(c) Periodica Polytechnica 2010

RESEARCH ARTICLE

\section{Structural analysis of the baroque parish church of Zsámbék}

\author{
Miklós Armuth / Dezsố Hegyi / András Árpád Sipos
}

Received 2011-04-07

\begin{abstract}
On the walls and vaults of the Roman Catholic Parish Church of Zsámbék cracks have long been observed. According to the parishioners, the crack widths have widened recently and new cracks have also appeared. This may have happened due to the increased traffic of the road beside the church.

In this paper we report on the structural analysis, including the investigation of vibrations induced by the traffic in the structural elements. We found that the weakness of the structural system of that age results from uneven settlement of the foundations due to the soil strata and constructional errors from the previous restorations. As the result of our analysis we recommended possible solutions for restoring the structural integrity of the church building.
\end{abstract}

\section{Keywords}

Structural analysis · historical buildings · cracks of masonry walls and vaults

\section{Miklós Armuth}

Dept. of Mechanics, Materials and Structures, BME, Múegyetem rkp. 1-3. K242, 1111 Budapest, Hungary

e-mail: armuth@arch.bme.hu

\section{Dezső Hegyi}

Dept. of Mechanics, Materials and Structures, BME, Múegyetem rkp. 1-3. K242, 1111 Budapest, Hungary

e-mail:dizso@szt.bme.hu

\section{András Árpád Sipos}

Department of Mechanics, Materials and Structures, BME, Múegyetem rkp. 13. K242, 1111 Budapest, Hungary

e-mail: siposa@szt.bme.hu

\section{Introduction, description of the building}

The construction of the Roman Catholic Parish Church of Zsámbék started in 1749 and it was finished in 1754 [9]. On 28 June 1763 an earthquake of M 6.3 [1] caused serious damage to the building. Due to the financial difficulties the restoration was completed only in 1792 . In the following century, the building was restored several times $(1810,1825,1854,1868,1883)$. In the $20^{\text {th }}$ century, the Second World War resulted in further serious damage.

The symmetrical building is a typical baroque structure with a $20.82 \mathrm{~m}$ maximum width and $38.97 \mathrm{~m}$ length. The average height of the walls are $11.0 \mathrm{~m}$, the height of the peak of the roof is $18.35 \mathrm{~m}$. The tower is integrated into the structure of the building above the main entrance; its height exceeds $36.00 \mathrm{~m}$ (Figs. 1, 2, 3 and 4).

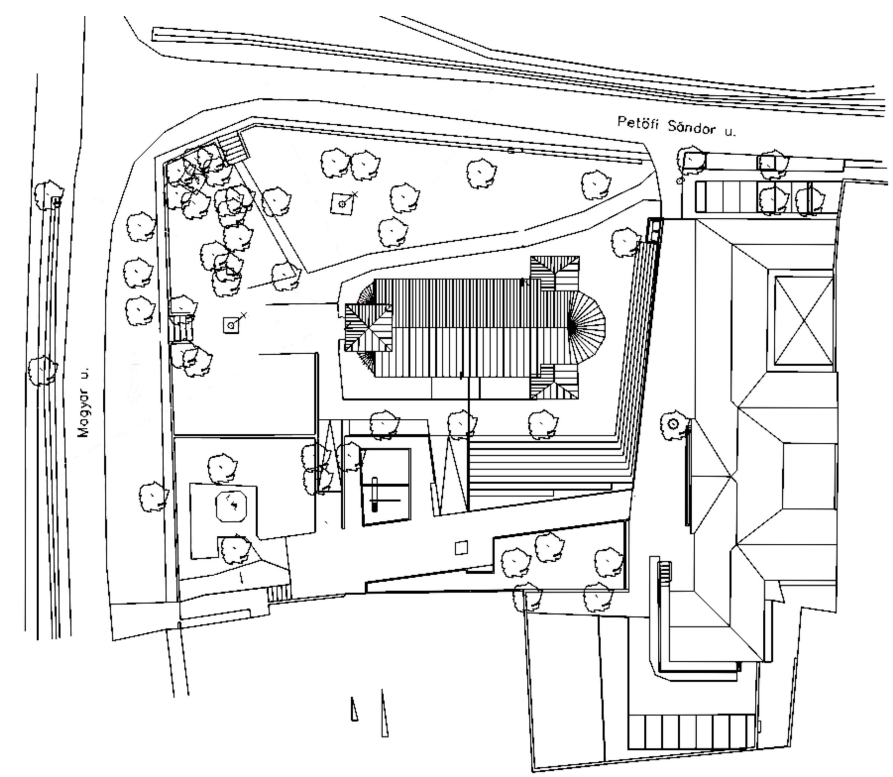

Fig. 1. The location of the Roman Catholic Church in Zsámbék (Drawing of XYZ Építész Stúdió Kft.

The church nave is covered by three domical vaults placed between four arches which are not supported by abutments. The alettes with their $5-10 \mathrm{~cm}$ offset are only ornaments without any structural purpose. The four arches have a nearly circular shape; 


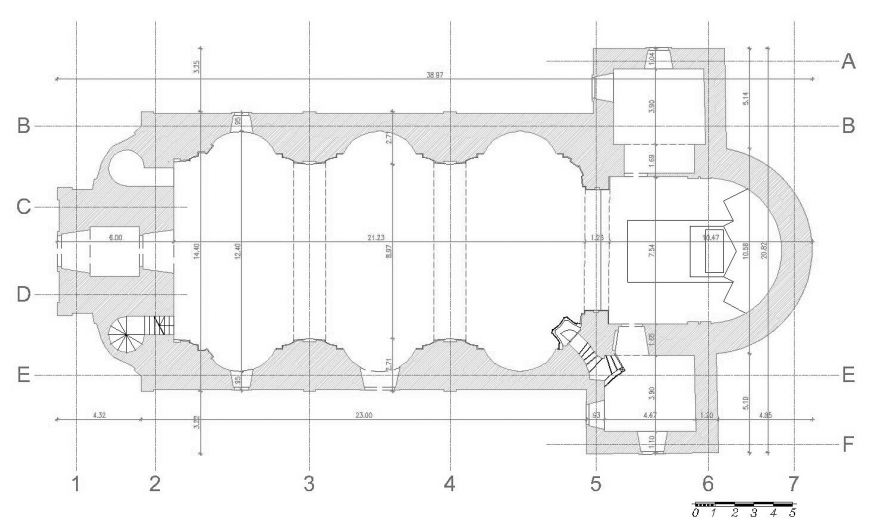

Fig. 2. The floor plan of the building (Drawing of XYZ Építész Stúdió Kft.)

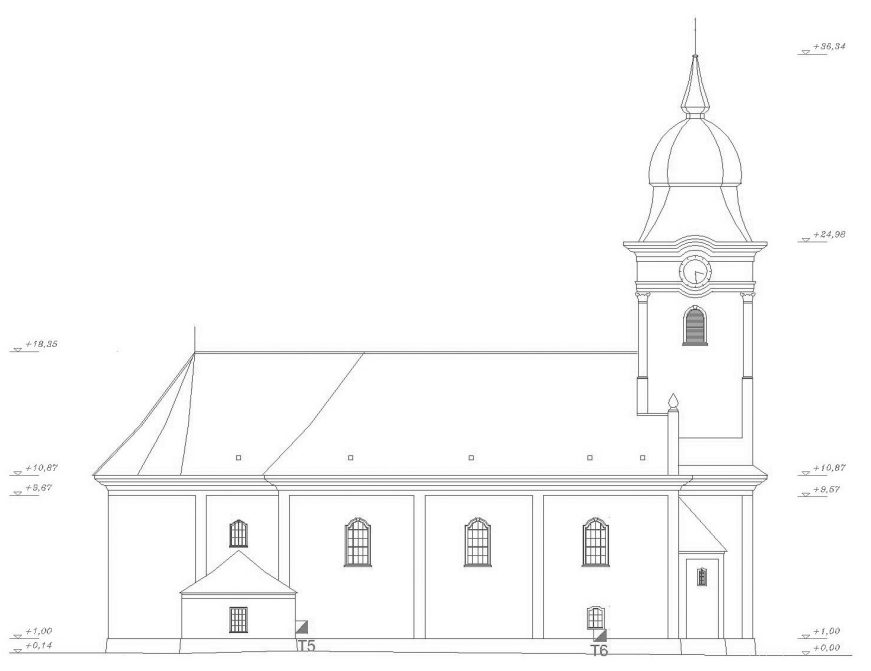

Fig. 3. The North-West elevation (Drawing of XYZ Építész Stúdió Kft.)

their width is approximately $1.70 \mathrm{~m}$. Each masonry vault covers a rectangular area and they have a ring-like brick course. Due to the small movements of the structure there is a slight difference between the actual geometry and the sphere in several locations of the vaults leading to concave surface segments. Similar vaults with a smaller span support the choir and cover the presbytery and the vestry.

Above the vaults a traditional Baroque timber roof was built. The structure is a main truss - secondary truss system.

On the walls and vaults, cracks have been observed for a long time. In this paper we summarize the results of the structural analysis and the probable reasons for the crack occurrence. The detailed data of the measurements can be found in [2]. The rest of the paper is organized as follows. In Section 2 we report the present state and the failures of the load bearing structures of the church. Section 3 contains the possible options for structural restoration. Section 4 concludes the material.

\section{Failures of the structures}

\subsection{The present condition of the structures}

Based on the Geotechnical Report [6] the two walls of the tower around the main entrance are founded in different soils. On the right side the boreholes showed $2.00 \mathrm{~m}$ humus soil over layers of muddy rock-flour and clay. On the left side of the main entrance the humus soil is only $1.80 \mathrm{~m}$ thick. Below it at $1 \mathrm{~m}$, calcareous clay over layers of clay can be found.

No ground water appeared in the boreholes; however the water content of the samples makes the presence of water probable. The levels of the foundations are 1.75-2.10 m below the ground, thus they are located near the upper level of the load bearing soil. Due to the differences in the soil layers and the slight changes in the foundations level, the load bearing capacity and the compression capacity differs under the walls of the building.

The limestone structural walls are irregular masonry. The strength of the stones according to the measurements by Schmidt hammer has a very high variation. For example in one location at the tower we found stones with a very low (3 MPa) and very high strength (13 $\mathrm{MPa})$ simultaneously. Lime-mortar with a low strength [0.5 MPa] was applied for the masonry making it very sensitive to cracks. The thickness of the nave walls varies between $0.90 \mathrm{~m}$ and $2.65 \mathrm{~m}$.

The main failures of the structural walls are vertical cracks, typically located around and above the windows (Fig. ??). The largest cracks appear in both longitudinal walls at the windows closest to the tower. The width of these cracks is between 0.4 and $0.7 \mathrm{~mm}$. There are more cracks on the NW wall facing to the main road of the village; several cracks can also be found around the vestry.

The vaults above the nave have longitudinal cracks of 1.0-3.0 $\mathrm{mm}$ width. These cracks also appear on the arches supporting the vaults.

The building was restored several times during its lifetime thus there might be cracks below the plastering and these maybe even wider than the observable ones.

The major failure of the timber roof is the disconnection between the masonry arches and the main rafters. Originally, inclined tie rods were connected to the main trusses to support the horizontal reactions of the main arches (Fig. 6). This structure has been modified several times resulting in a higher position of the tie beams of the main trusses and separation of the inclined tie rods and the main trusses.

\subsection{The vibration analysis}

The recently increased traffic on the neighbouring road may explain the increase of crack widths. To validate this hypothesis a detailed vibration analysis was carried out on the building by acoustic expert Péter Fórián Szabó [4].

Altogether 20 trucks passing on the road and the effects of the bell ringing were recorded and analyzed. According to the present state of the building and the length of the vibrations induced by the traffic the assessment must be based on the speed 


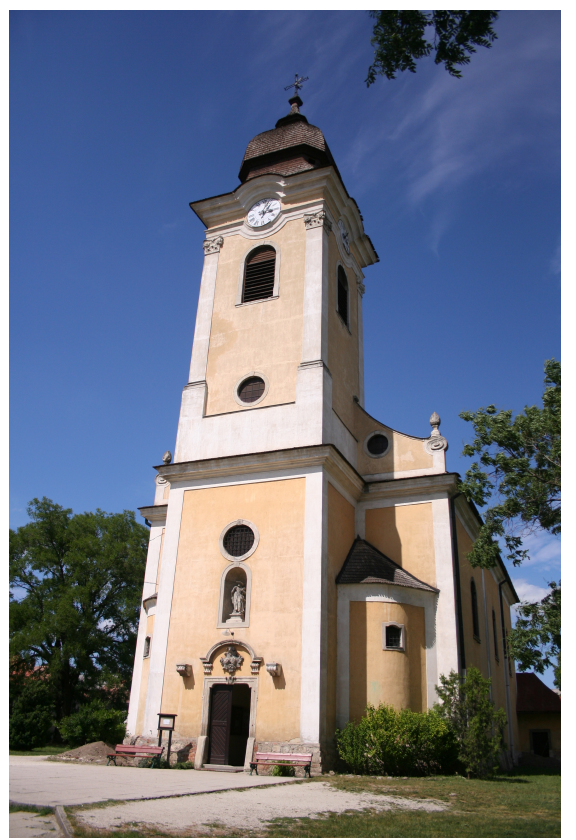

Fig. 4. Views of the main entrance and the South-East side of the building
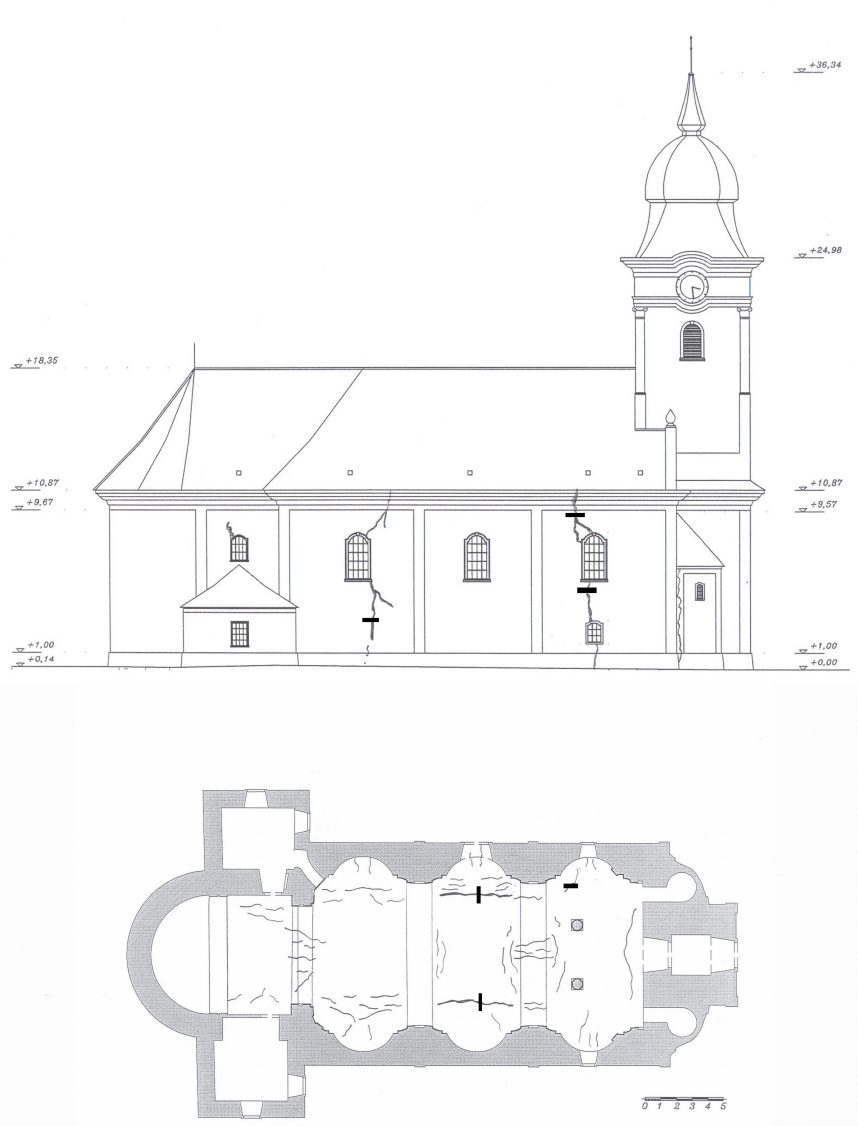

Fig. 5. The patterns of the visible cracks on the structural walls and the vaults(black boxes on the largest cracks)

of the vibrations. Based on this the following conclusions are straightforward:

1 The vertical vibrations on the bottom and at the top of the structural walls have an approximately identical amplitude.

2 The amplitude of horizontal vibrations of the structural walls

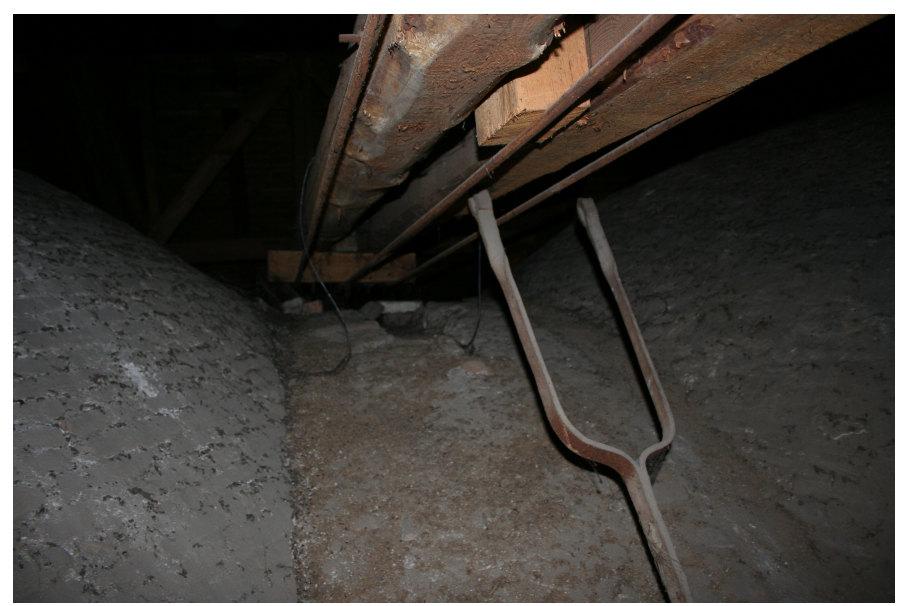

Fig. 6. Disconnected tie-bar over a main arch.

at the level of the arches is about 2-3 times bigger, than the vertical vibrations.

3 The largest amplitudes were measured at the vaults.

4 The truck traffic induces about a 5 times bigger amplitude than the church bells.

5 The detailed analysis revealed a possible rigid connection between the road and the building. For example a vaulted passage to one of the opposite buildings or a sewer pipe can explain the measurements.

According to the results the vibrations induced by the traffic on the road are not the main reasons for the presence of the cracks; however the heavy truck traffic explains the dominance of the cracks at the NW structural wall facing the road, and the recent increase in the crack widths. 


\subsection{Results of the structural analysis}

The dead loads were approximated from the geometry of the building and the densities commonly used in practice. The live loads for the slabs were taken into account with the following values:

choir: $\quad 3.00 \mathrm{kN} / \mathrm{m}^{2}$, partial safety factor: 1.30

loft: $\quad 1.50 \mathrm{kN} / \mathrm{m}^{2}$, partial safety factor: 1.40

slabs in the tower: $\quad 1.50 \mathrm{kN} / \mathrm{m}^{2}$, partial safety factor: 1.40

Snow and wind loads were considered according to the Hungarian Code MSZ 15021/1-86 [3].

The calculation of the loads on the foundations revealed that there are close to $100 \%$ higher stress levels acting below the foundations of the tower (approximately $500 \mathrm{kN} / \mathrm{m}^{2}$ ) than below the walls of the nave (approximately $210 \mathrm{kN} / \mathrm{m}^{2}$ ). We note that a resistance of $300 \mathrm{kN} / \mathrm{m}^{2}$ was given for the soil in the Geotechnical Report [6].

The higher settlement due to the higher stresses in the soil around the main entrance separates the tower and the connecting part of the nave from the remaining walls. This separation takes place at the weakest cross section of the nave walls, namely at the location of the closest window to the tower (Fig. 5). At this point, not only the opening for the window, but the narrower width weakens the wall. Furthermore the different layering of the soil leads to an uneven settling under the foundations resulting in additional stresses in the masonry.

Although there is comprehensive literature on modelling vaults [7, 8], to gain a detailed insight to the structural behaviour the structural analysis was carried out by a finite element code FEM Design 8.0. We used triangular plate elements to model the vaults and the arches (Fig.77). Due to the unclear connection between the structural walls and the vaults we applied a hinged line support only below the arches. The computational results confirm that the resistance of the masonry vaults is satisfactory in all the relevant load combinations.

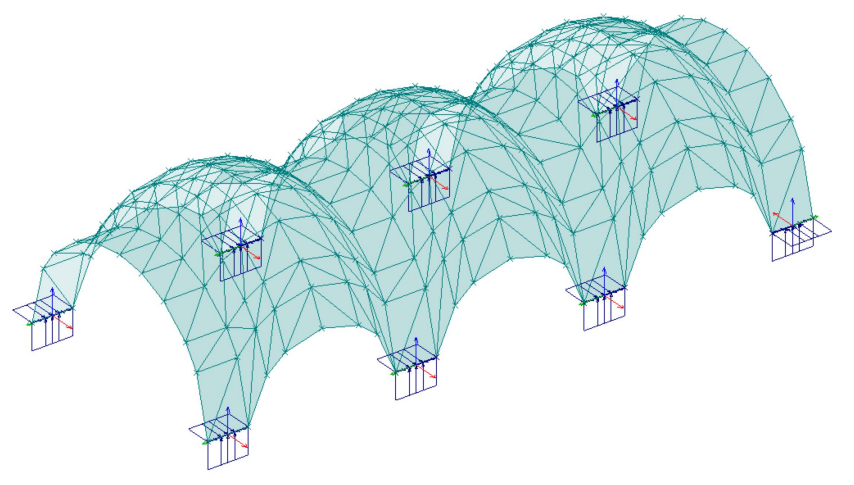

Fig. 7. The FEM model of the vaults and the arches

Due to the separation of the tie rods, the horizontal reactions of the vaults and arches are transferred to the top of the structural walls. The thrust computed for this load remains inside the wall and the maximal stress does not exceed 4.0 MPa thus the structure can be regarded as safe.

\section{Assessment of the failures}

The occurrence of cracks - even in the case of homogenous soil and appropriate foundations - is typical among baroque churches for the following reasons:

1 the vaulted slabs transfer a horizontal force to the walls

2 there is no such structural element (i.e. a steel or RC ring beam) on the top of the walls which assists in sharing the horizontal loads between the walls. The tie-beams of the roof are not sufficient for this purpose, and they have been removed or cut every so often.

3 the mortar used for the masonry has typically low tensile strength, it cracks at a very low level of tension.

In the case of the Zsámbék Church the first occurrence of the cracks was due to the earthquake in 1763. A cracked structure in spite of restoration - is more sensitive even to small displacements.

As we mentioned before, the higher settlement under the tower is one of the reasons for the movements. It explains the location of the largest cracks. This kind of failure is typical among churches built in a similar manner. However, the displacements have not just originated from settling. The separation of the tie rods and the main truss is a serious defect. Although the walls are safe from the horizontal reactions transferred from the vaults, the reactions lead to considerable horizontal displacements. These movements have generated the cracks on the lover surface of the vaults.

To limit the further increase in the crack widths and the occurrence of new cracks the tie rod connection between the arches and the main trusses of the roof must be restored. The position of the masonry around the cracks should be fixed by the application of steel elements. We suggest using the "Brutt Saver" system for this purpose. To assist the distribution of the horizontal loads steel $\varnothing 30 \mathrm{~mm}$ bars should be placed on the top of the walls. Steel plates are needed at the end to provide efficient anchorage for the bars. A slight prestress should be applied to the bars, and a device for future prestressing should be integrated.

\section{Conclusion}

In this paper we reported about the structural failures of the Roman Catholic Church of Zsámbék. Our investigations and analysis revealed that the typical structural mistakes of the Baroque churches, such as insufficient support against the horizontal thrust of the vaults, the uneven distribution of stresses at the level of foundations and the unclear interplay of secondary effects meet with unfavourable soil conditions and serious mistakes from previous restorations. The vibration of the passing road is responsible for the higher crack widths on the side facing the road, but it is not the main reason for the observable crack patterns. A moderate restoration, which takes the overall behaviour of the structure into account can impede further crack propagation as long as the major part of the settling of the underlying soil has finished. 

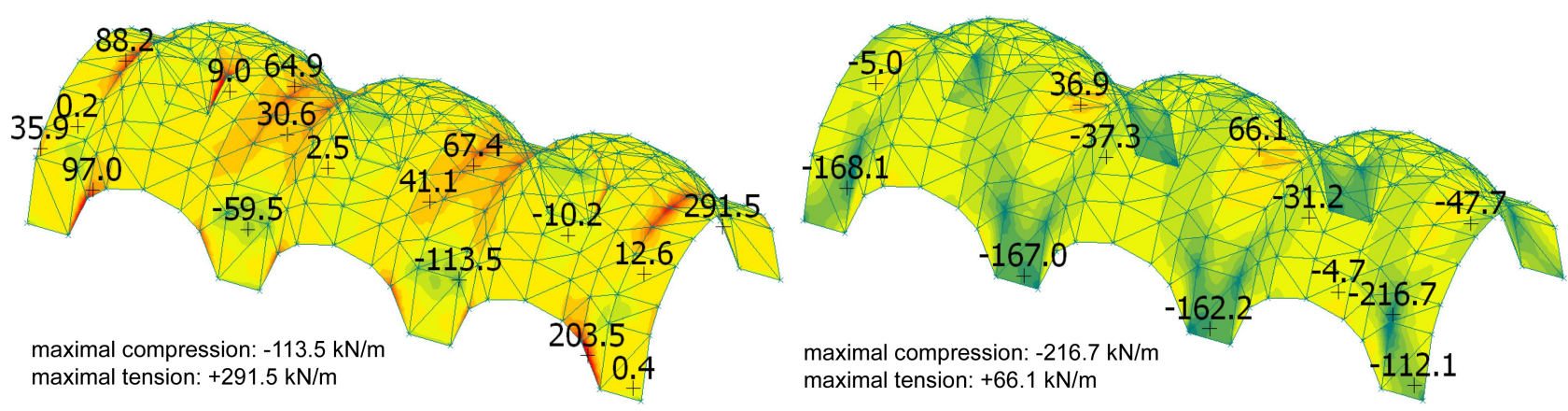

Fig. 8. The computational results: the maximal principal surface forces $\mathrm{N}_{1}$ (on the left) and $\mathrm{N}_{2}$ (on the right)

\section{References}

1 Dulácska E, Joó A, Kollár L, Tartószerkezetek tervezése földrengési hatásokra, Akadémiai Kiadó, Budapest, 2008.

2 Armuth M, Hegyi D, Sipos A A, Tartószerkezeti Szakvélemény a zsámbéki római katolikus templom tartószerkezeteiról, BME Department of Mechanics, Materials and Structures, 2009.

3 MSZ 15021/1-86, Hungarian Code MSZ: Loads on building structures. in Hungarian.

4 Flórián Sz P, A zsámbéki római katolikus templom rezgésvizsgálata. manuscript, Archive of the Catholic Parish at Zsámbék (2009), by the kind permission of the author.

5 Armuth M, Hegyi D, Sipos A A, Az érdi Szent Mihály Római Katolikus templom tartószerkezeti vizsgálata és rekonstrukciója, Építés Építészettudomány (2010). in press.

6 Túróczi G, Talajmechanikai szakvélemény. manuscript, Archive of the Catholic Parish at Zsámbék (2004), by the kind permission of the author.

7 Dulácska E, Boltozatok, Magyar Építôipar 11-12 (1994).

8 Peck T, Falazott boltivek hagyományos elmélete, Építés Építészettudomány XXXI (2003), no. 1-2, 69-104.

9 Dercsényi D, Pest megye múemlékei I-II., Magyarország Múemléki topográfiája V., 1958, pp. 496-504. 